\title{
Addressing the Computing Gender Gap: A Case Study of Visual Culture Art Education and Feminist Poststructuralist Pedagogy
}

\author{
Melinda Rhaodes \\ The Ohio State University
}

\section{Introduction}

For the past two summers, I have served as the outside evaluator for Digital Animation: A Technology Mentoring Program for Young Women at the Advanced Center for Computing and Design (ACCAD) at The Ohio State University (http://accad.osu.edu/womenandtech/). This program teaches a group of young women to use Maya ${ }^{\circledR}$ 3-D animation software, along with other digital and computer technologies, in order to create animations about a local environmental issue over the course of an intensive two-week program. The $15-18$ young women (rising $8^{\text {th }}, 9^{\text {th }}$, and $10^{\text {th }}$ graders) accepted to the program work in small groups, each with a female college-aged mentor. The program aims to use intensive instruction and support to increase and sustain participating girls' skills and interest in technology. Additionally, Digital Animation strives to influence young women to pursue additional computer education and consider careers in computer-related fields in an attempt to address a gender gap in computer technology fields and programs (Margolis \& Fisher, 2003). My research is a case study of the Digital Animation program, particularly using the theoretical lenses of visual culture art education (VCAE) and feminist poststructuralist pedagogy to explore and analyze the program and any overlaps, tensions, and disconnects among these research lenses or the practices of the program.

\section{Visual Culture Art Education (VCAE)}

Within the past six decades, Art Education has evolved from Lowenfeld's (1947) focus on the "physical, mental, social, and emotional growth that children experience by drawing, painting, and sculpting" (p. 9), to the discipline based art education (DBAE) orientation and validation of the 1980s (Wolbier, 2003), to today's movement toward visual cultural studies (Sanders, in press) and VCAE. Tavin (2005b) documents a four-decade progression in art education, from Vincent Lanier through June King McFee, Laura Chapman, and Brent and Marjory Wilson, underlying current VCAE discourses. Not all art educators, however, advocate VCAE; many favor formalist and self-expressive goals, as well as a continued adherence to a canon of Western masterpieces and traditional evaluation criteria (Kamhi, 2003; Kamhi, 2004; Smith, 2003; Stinespring, 2001; Stinespring \& Kennedy, 1995). Much resistance toward visual cultural studies stems from visual culture proponents' acceptance of anything visual as valid for critical exploration, including newer media (print advertisements, web pages, reality television, and computer-based artistic endeavors), as well as its emphasis on increased attention to the contexts in which art is made and viewed, often over formal concerns (Ballengee-Morris \& Stuhr, 2001; Duncum 1999, 2000, 2001, 2002, 2003; Elkins, 2003; Freedman, 1994, 1997, 2000, 2003; Freedman \& Stuhr, 2004; Tavin, 2000, 2003, 2005a, 2005b; Tavin \& Anderson, 2003).

This case study has three primary areas of concern when using VCAE to explore the program: technology, critical pedagogy and power, and production aspects. Of particular importance to the case study of Digital Animation is VCAE's validation and acceptance of multiple media, including strong arguments for including computer-related works (Carpenter \& Taylor, 2003; Duncum, 2002; Freedman, 2003; Freedman \& Stuhr, 2004; Mirzoeff, 1999; Taylor, 2004). Freedman (2003) also advocates strongly for the inclusion of computer media 
within VCAE, noting the mainly visual experience and pervasiveness of computers and technology, including the ability to nearly infinitely reproduce and transmit imagery.

Other scholars (Duncum, 2002; Giroux, 2004) stress the critical pedagogy foundations of VCAE and its concerns with politics/power. These scholars see VCAE's potential as a "political intervention," encouraging constructing and applying knowledge and examining "how knowledge, values, desire, and social relations are always implicated in relations of power" (Giroux, 2004, p. 34). Additionally, scholars are considering how to use VCAE "to fight deeply rooted injustices in a society and world founded on systemic economic, racial, and gendered inequalities" (Giroux, 2004, p. 35).

Another key aspect of VCAE is its focus on production of visual images as participation in and response to visual culture (Duncum, 2003). Duncum acknowledges that teaching contemporary art practices "does not involve ... a radical rethinking" of art education curricula (p. 19), and notes that "a substantial amount of practice now [is] a form of critique" (p. 23). Because the Digital Animation program centers on producing an end product animations, examining the program with respect to issues of production will be informative.

\section{Feminist Poststructuralist Pedagogy}

This study also includes a focus on feminist theories, which are inextricably intertwined with the pedagogy of Digital Animation. Feminist theory is action-oriented and critical - aimed at questioning theory and practice to create improvement through change. Feminist theory also aims to deconstruct current social hierarchies and beliefs that oppress women and other minorities. In terms of research orientation, feminist research is not only usually womancentered, but also "reflexive and...critical of accepted epistemologies and methodologies. Feminist research should adopt epistemological and methodological perspectives that are appropriate both to its research questions and to its emancipatory aims" (Malson, 1998). Malson recommends employing feminism as theory and as a practice within educational contexts, and my case study examines its employment within an Art Education context.

Feminist pedagogy and research, in general, also stresses the "importance of social responsibility and action as important to feminist ideals and to liberatory education. Social action moves academic theory into the realm of the experiential, commitment, and social change" (Garber, 2003). In education, according to Kimmel (1999), feminist pedagogy seeks to value "Holistic learning that integrates feelings with cognition and experience, making connections between the personal and the socio-political - including multiple sources of knowledge, and learning goals that include increased self-awareness and personal growth are important feminist principles that relate to the emotions" (in Garber, 2003). My research will attempt to address these issues within the program, and also with respect to the research process and data itself.

An increasing body of art educators has discussed the influence of feminist perspectives and applied feminist pedagogical practices within Art Education (Garber 1996, 2002, 2003; Garber \& Gaudelius, 1992; Gaudelius, 1997, 2000; Hicks, 1991; Keifer-Boyd 2003, 2004; Keifer-Boyd, Bobbitt, Dellasega, Hill, \& Philak, 2003; Keifer-Boyd \& Hill, 2001; Sandell, 1991; Sandell \& Spiers, 1999). VCAE advocates also call for applying critical theories, such as feminist theories, to VCAE (Duncum, 1989, 2003; Elkins, 2003; Tavin, 2003). More commonly, transdisciplinary visual culture scholars (Jones, 2003) apply feminist theory to visual culture in fields like film studies (Mulvey, 1984), managing to explore and validate a diverse range of visual culture objects of study (de Lauretis, 1988; Kaplan, 1983, 1992; Storey, 1988). Interestingly, VCAE scholars have not produced much research about the relationships between VCAE and feminist pedagogy. 
Through the case study of Digital Animation, I will more particularly employ and analyze evidence of feminist poststructuralist pedagogy, which comprises previously mentioned feminist concerns but additionally focuses on poststructuralist questions of language, subjectivity, and power (Weedon, 1997). In these respects, my case study aims to provide information about the Digital Animation program in relation to program goals, particularly with relation to VCAE, feminist poststructuralist pedagogy, and gender \& technology research.

Another concern of importance to the feminist poststructuralist aspects of this case study is representation. Throughout the research I will need to continuously grapple with ways to represent the participants and the program that are accurate given my theoretical frameworks and with ways to do this in a manner that respects the individuals and organizations involved in this research. Additionally, because this research comes from a feminist tradition, I want to ensure that the research and analysis benefits the program and participants as well as me.

\section{Bridging the Gender Gap in Technology}

Because computer and digital technologies play increasingly prominent roles as cultural media and mediators, the documented gender inequity in computer technology fields is particularly troubling (Margolis \& Fisher, 2003). Margolis and Fisher (2003) argue that the greatest impact of the absence of women in computer sciences "may be on the health of computing as a discipline and its influence on society" (p. 2). ACCAD's Digital Animation program employs feminist poststructuralist pedagogy within an arts-based program to address this technology gender gap and increase girls' interest and skill level with technology as well as their likelihood of considering Science, Technology, Engineering, and Mathematics (STEM) fields as a result of their program experiences.

Foundational feminist technology theory's considerations of the potential of technology to alter gender perceptions and limitations (Haraway, 1991) has evolved into contemporary positioning of girls in relation to technology as reticent (Healy, 1999; Huff, et al, 1992; Turkle, 1986), negatively valued (Badagliacco, 1990; Patterson, 1984), and distanced or minimally present (Klawe \& Leveson, 1995; Margolis \& Fisher, 2003; Spertus, 1991). Importantly, feminist research offers tools aimed toward practical insights and possibilities for change related to gender and technology (Clarke, 1992; Hesse-Biber \& Gilbert, 1994). This case study will analyze research about gender and technology issues and explore areas where the literature supports data from ACCAD and where there are tensions and conflicts.

\section{Significance of Study}

The proposed case study operates at the intersections of VCAE and feminist

poststructuralist pedagogy with the gender gap in technology, and can provide useful information about each area individually and cumulatively in relationship with one other. Additionally, exploring these areas may lead us to develop ways to encourage young women to pursue computer and STEM education and career possibilities through VCAE. Elkins (2003) posits that the current visual culture debate in Art Education is too narrowly focused on defining and validating the objects worthy of study and needs to be more complicated. To this end, Elkins echoes other art educators (Boughton, et. al., 2002; Tavin, 2003) who call for applying critical theories from other fields to visual culture. My research seeks to use previous feminist (poststructuralist) scholarship in art education to inform this case study. This case study will explore VCAE aspects of the program in relationship with feminist poststructuralist pedagogy as a means to answer calls for scholarship combining visual culture with critical theories.

This research will also be significant in terms of depicting and analyzing some of the complex interrelationships between gender and technology and visual culture. Some scholars 
write about gender and technology issues in general (Badagliacco, 1990; Haraway, 1991; Kramer \& Lehman, 1990; Turkle, 1995; Ullman, 1995), some about gender issues in art education (Colbert, 1996; Collins \& Sandell, 1996; Daniel, 1996; Garber, 2003b, 2003a, 2002, 1996; Gaudelius, 2000; Sandell \& Speirs, 1999), and a few write about technology issues in art education (Harris, 1997; Taylor, 2000). In contrast, there is little, if any, scholarship on gender and technology issues in relation to VCAE. This study proposes to generate data and analysis about these interrelationships.

Also, studies about gender and technology have been primarily focused on college-aged women in computing from a science and mathematics perspective (Margolis \& Fisher, 2003). This research builds on that by adding an arts-based perspective and by focusing on middle and high school girl participants, adding multiple layers of information to research on gender and technology.

Finally, Freedman (2004) advocates that we, in Art Education, should do more research that serves to document, apply, validate, trouble, and develop grounded theory. This case study is an attempt to gather and create data, apply VCAE and feminist poststructuralist assertions and principles to a particular case, use this case to validate and trouble previous assumptions, assertions, and applications. Also, because this study explores these complicated intersections of theory and practice, it should help validate the transdisciplinary nature and value of VCAE. Most importantly, although the scope of this research may not include developing theory, the case can provide an important foundation for later work more fully exploring these possibilities.

\section{The Research Plan}

This case study focuses on the complex intersection of feminist poststructuralist pedagogy and VCAE with a program addressing gender gap in technology. Qualitative study is necessary to make sense of the "complex, unstructured data [in this program] from which new understandings might be derived" (Morse \& Richards, 2002, p. 25), and because the data "demand it" (p. 26).

My research begins by characterizing the Digital Animation program within more general feminist theoretical frameworks and contexts (Butler, 1990; de Beauvoir, 1949/1972; Wittig, 1981) and moves to analyzing facets of the program related to feminist poststructuralism (Ellsworth, 1989; Lather, 1991; Luke \& Gore, 1992; Orner, 1996; Weedon, 1997) and feminist poststructural pedagogical practices as an application of feminist theory (Belenky, et al, 1986; Daniel, 1996; Gillbert, 1999; hooks, 1989; Jacobs, n.d.; Jacobs \& Becker, 1997; Luke \& Gore, 1992; Orner, 1996; Relke, 1994; Ritchie, 1990; Sandell, 1991; Tisdell, 1998; Weiler, 1988).

This research is interested in exploring the complexity of the data from the Digital Animation program for young women to describe and understand how the program functions, particularly in relationship to using VCAE and feminist poststructuralist pedagogy to bridge the technology gender gap, providing "rich descriptions of the social world" according to the "specifics of [this] particular case" (Denzin \& Lincoln, 2000, p. 10). The case study approach is "congruent with "a fit among question, method data, and analytic strategy" (Morse and Richards, 2000, p. 4), and with administrator concern for understanding the interactions of complex factors and changing responses related to the gender gap in technology and effective approaches for bridging it.

\section{Research Questions}

I enter my case study with a body of data I collected over the 2004 and 2005 sessions of Digital Animation at ACCAD. This program aims to address the problem of low numbers of females pursuing computer education and careers, or what Margolis \& Fisher (2003) term the "gender gap" in technology education and employment. My duty to this program is to evaluate 
how well the program addresses the gender gap in technology education and employment by generating interest and potential further pursuit of computer education and careers. Arising from my experiences are my questions as a researcher about how this program operates with respect to feminist poststructuralist pedagogy and research on gender and technology as it attempts to address this gender gap. In this way, the overarching question of this research is: How does the ACCAD Digital Animation summer technology mentoring program for young women address the gender gap in computer education and careers, specifically with respect to VCAE and feminist poststructuralist pedagogy? Questions subsumed under this larger concern include: What can be learned about VCAE from this program? What can be learned about feminist poststructuralist pedagogy from this program? And, What can be learned about the relationships between gender and technology from this program?

\section{Research Methodology: Case Study}

My research aims to address the larger question of "What can be learned from this case" (Stake, 2000, p. 436) by providing "thick description" (p. 439) of the case and its issues. This thick description offers "a richness and depth of information not usually offered by other methods" (Hancock, 1998, p. 6). In Art Education, Eisner (1991) advocates case studies as a means to demonstrate the complexity of how the arts function in educational practice, for understanding this particular case (intrinsic case study) and support insight and "understanding of something else" (instrumental case study)(Stake, 2000, p. 437). This research study will develop a deeper understanding of Digital Animation as a case, along with a better understanding of how VCAE and feminist poststructuralist pedagogy can interact to address the gender gap in technology.

\section{Participants}

Case study necessitates great attention to the composition of participant groups, with special attention to issues of selection and demographic information. This case study involves the specific set of participants, mentors, administrators, and parents from ACCAD's 2004 and 2005 sessions of Digital Animation. The participants are recruited from the local public school district and through newspaper ads and ACCAD's website. The recruits are (mostly) entering 8th, 9th, or 10th grade the following year. No previous technology experience is necessary, but applicants need to be "interested in art and design" and "enthusiastic about exploring the creative possibilities through technology" (www.accad-osu.edu). The program is free and lasts two weeks from 9 a.m. to 4 p.m., but participants are responsible for their own transportation to and from campus. Factors such as these affect which students apply and participate.

Program mentors consist of women graduate students in ACCAD's programs. They have a demonstrated interest in technology, and are chosen based on their willingness to work with the girls during the duration of the program and to serve as female mentors and role models for them in the field of computer technology. Program administrators and parents are also included within the case study of the program to provide a more complete, full, rich study by offering additional context for each girl's experience and for assessing the impact of the program. Finally, as an inherent part of feminist research, I will reflexively consider my own roles in this research and how they may impact the research and the program.

\section{Research Methods}

This case study is based on my research as an outside program evaluator for the Digital Animation program and my theoretical "assumptions" for understanding the social reality of the case being studied (Morse \& Richards, 2001, p. 4-5). I developed an observation and evaluation framework based on a review of research methods employed by past researchers 
(before 2004), including observation (Angrosino \& Mays de Perez, 2000), field notes, preprogram and post-program surveys, focus group interviews, individual interviews, interest inventories, and evaluation material/data generated by the researchers. The methods I used for 2004, based on this review, included formal and informal interviews, observations/field notes, pre-program and post-program surveys, reflexive memos, and a formal program evaluation report. For 2005, I again reviewed previous data and notes and modified my data collection methods. During 2005, I continued all practices from 2004 and added parent informal interviews and post-surveys based on anecdotal observations and interactions. I augment the qualitative approach by including quantitative methods, mainly surveys, to generate, analyze, tabulate, and validate data.

\begin{tabular}{|l|c|c|}
\hline Research Methods for Digital Animation Case Study & $\mathbf{2 0 0 4}$ & $\mathbf{2 0 0 5}$ \\
\hline Pre-program surveys (girls) & $\mathrm{X}$ & $\mathrm{X}$ \\
\hline Post-program surveys (girls) & $\mathrm{X}$ & $\mathrm{X}$ \\
\hline Pre-program surveys (mentors) & $\mathrm{X}$ & $\mathrm{X}$ \\
\hline Post-program surveys (mentors) & $\mathrm{X}$ & $\mathrm{X}$ \\
\hline Formal Interviews (girls) & $\mathrm{X}$ & $\mathrm{X}$ \\
\hline Informal Interviews (girls) & $\mathrm{X}$ & $\mathrm{X}$ \\
\hline Formal Interviews (mentors) & $\mathrm{X}$ & $\mathrm{X}$ \\
\hline Informal Interviews (mentors) & $\mathrm{X}$ & $\mathrm{X}$ \\
\hline Formal Interviews (administration) & $\mathrm{X}$ & $\mathrm{X}$ \\
\hline Informal Interviews (administration) & $\mathrm{X}$ & $\mathrm{X}$ \\
\hline Post-surveys (parents) & & $\mathrm{X}$ \\
\hline Informal interviews (parents) & $\mathrm{X}$ \\
\hline Observations/field notes & $\mathrm{X}$ & $\mathrm{X}$ \\
\hline Reflexive memos & $\mathrm{X}$ & $\mathrm{X}$ \\
\hline Formal Program Evaluation Report & $\mathrm{X}$ & $\mathrm{X}$ \\
\hline Comparative Analysis with Formal Objectives & $\mathrm{X}$ & \\
\hline Web Pages with Digital Animation finished projects & $\mathrm{X}$ & $\mathrm{X}$ \\
\hline Videotape of end presentation & & $\mathrm{X}$ \\
\hline
\end{tabular}

\section{Data Analysis}

Along with data collection, I will incorporate data analysis methods for qualitative case study research, including generating analytic memos and the process of reflexively analyzing those memos in conjunction with other program data (Lincoln \& Guba, 2000, p. 183), writing (Richardson, 2000, p. 923), and employing a two-step data coding process, constructing conceptual analysis, sampling to refine the my emerging theoretical ideas, and integrating my theoretical frameworks (Charmaz, 2000, pp. 510-511). I will perform member checks and follow-up interviews, in addition to surveying, to triangulate and validate data (Stake, 2000, p. 443

\section{References}

Angrosino, M. \& Mays de Perez, K. (2000). Rethinking observation: From method to context. In N. Denzin \& Y. Lincoln (Eds.), The handbook of qualitative research $\left(2^{\text {nd }}\right.$ ed.) (pp. 673702). Thousand Oaks, California: Sage. 
Badagliacco, J. M. (1990). "Gender and race differences in computing attitudes and experience." Social Science Computer Review. 8(1), 42-64.

Ballengee-Morris, C. \& Stuhr, P. (2001). Multicultural art and visual cultural education in a changing world. Art Education. July, 2001.

Belenky, M, Clinchy, B., Goldberger, N., \& Tarule, J. (1986). Women's Ways of Knowing. New York: Basic Books, Inc.

Boughton, D., Freedman, K., Hausman, J., Hicks, L., Madeja, S., Metcalf, S. Rayala, M., SmithShank, D., Stankiewicz, M., Stuhr, P., Tavin, K., \& Vallance, E. (2002). Art education and visual culture. NAEA Advisory. Reston: NAEA>

Butler, J. (1990). Gender trouble: Feminism and the subversion of identity. London: Routledge.

Carpenter, B.S. II., \& Taylor, P. (2003). Racing thoughts: Altering our ways of knowing and being in art through computer hypertext. Studies in Art Education, 45(1), 40-55.

Charmaz, K. (2000). Grounded theory: objectivist and constructivist methods. In N. Denzin \& Y. Lincoln (Eds.), The handbook of qualitative research ( $2^{\text {nd }}$ ed.) (pp. $\left.509-536\right)$. Thousand Oaks, California: Sage.

Clarke, V. (1992). Strategies for involving girls in computer science. In C. Martin \& E. MurchieBeyma (Eds.), Search for gender free paradigms for computer science education (pp. 509 - 536). Eugene, OR: International Society for Technology in Education.

Colbert, C. (1996). Issues of gender in the visual arts education of young children. In G. Collins \& R. Sandell (Eds.), Gender issues in art education: Content, contexts, and strategies (pp. 60-69). Reston, VA: NAEA.

Collins, G., \& Sandell, R. (Eds.). (1996). Gender issues in art education: Content, contexts, and strategies. Reston, VA: NAEA.

Daniel, V. (1996). Womanist influences on curricular ecology. In In G. Collins \& R. Sandell (Eds.), Gender issues in art education: Content, contexts, and strategies. Reston, VA: NAEA.

de Beauvoir, (1972). The second sex. (H.M. Parshley, Trans.). New York: Penguin. (Original work published in 1949).

de Lauretis, T. (1988). Aesthetic and feminist theory: Rethinking women's cinema. In E.D. Pribam (Ed.), Female spectators: Looking at film and television (pp. 174 - 195). London: Verso.

Denzin, N. \& Lincoln, Y. (Eds.). (2000). The handbook of qualitative research ( $2^{\text {nd }}$ ed.). Thousand Oaks, California: Sage.

Duncum, P. (1989). Toward foundations for a socially critical art education. Journal of Social Theory in Art Education, 9, 12 - 25.

Duncum, P. (1999).A case for an art education of everyday aesthetic experiences. Studies in Art Education, 38(2), 69-79.

Duncum, P. (2000). Defining visual culture for art education. Journal of Multicultural and Cross-cultural Research in Art Education, 18(1), 31-36.

Duncum, P. (2001). Visual culture: Developments, definitions, and directions for art education. Studies in Art Education, 42(2), 101-112.

Duncum, P. (2002). "Visual culture art education: Why, what and how." International Journal of Art \& Design Education, 21(1), 14 - 23.

Duncum, P. (2003). The theories and practices of visual culture in art education. Arts Education Policy Review, 105(2), 19-25.

Eisner, Elliot W. (1991) The enlightened eye: qualitative inquiry and the enhancement of 
educational practice. New York: Macmillan.

Elkins, J. (2003). Visual studies: A skeptical introduction. New York: Routledge.

Ellsworth, E. (1989). Why doesn't this feel empowering? Working through the repressive myths of critical pedagogy. Harvard Educational Review, 59(3), 297-324.

Freedman, K. (1994). Interpreting gender and visual culture in art classrooms. Studies in Art Education, 35(3), 157-170.

Freedman, K. (1997a). Critiquing the media: Art knowledge inside and outsideof school. Art Education, 50(4), 46-51.

Freedman, K. (1997b). Visual art/virtual art: Teaching technology for meaning. Art Education, $50(4), 6-12$.

Freedman, K. (2000). Social perspectives on art education in the U.S.: Teaching visual culture in a democracy. Studies in Art Education, 41(4), 314-329.

Freedman, K. (2003). Teaching visual culture. New York: Teacher's College Press.

Freedman, K. (2004). Becoming a researcher in art education: Constructing theory based on research. Studies in Art Education, 45(4), 283- 284.

Freedman, K. \& Stuhr, P. (2004). Curriculum change for the $21^{\text {st }}$ century: Visual culture in art education. In Day, M. \& Eisner, E. (Eds.), Handbook of research and policy in art education. Mahwah, NJ: Lawrence Erlbaum Associates.

Garber, E. (1996). Art criticism from a feminist point of view: An approach for teachers. In G. Collins \& R. Sandell (Eds.), Gender issues in art education: Content, contexts and strategies, pp. 21-29. Reston, VA: National Art Education Association.

Garber, E. (2002). Post 9/11: Politics, diversity, and multiculturalism in art education. Journal of Cultural Research in Art Education, 19-20, pp. 36-46.

Garber, E. (2003). Feminism, aesthetics, and art education Studies in Art Education, 33(3), p. $210-25$.

Garber, E. (2003). "Teaching about gender issues in the art education classroom: Myra Sadker Day." Studies in Art Education. 45(1), pp. 56 - 72.

Garber, E. \& Gaudelius, Y. (1992) Object into subject: Feminism, art, education, and the construction of the self. Canadian Review of Art Education, 19 (1), pp. 12-33.

Gaudelius, Y. (1997). Postmodernism, feminism and Art Education: An elementary art workshop based on the works of Nancy Spero and Mary Kelly. In J. Hutchens \& M. Suggs (Eds.), Art Education: Content and Practice in a Postmodern Era. Reston, VA: National Art Education Association.

Gaudelius, Y. (2000). Radical Pedagogies: Overlaps, Tensions and Fruitful Encounters." In D. E. Fehr, K. K. Fehr, and K. Keifer-Boyd (Eds.), Real world readings in Art Education: Things your professors never told you. New York: Falmer Press.

Gillbert, C. (1999). "Is there a difference between good teaching and feminist pedagogy?" (Reprinted from the January 25, 1999 edition of the STLHE Newsletter). http://www.uregina.ca/tdc/FeministPedagogy.htm. Accessed on May 14, 2005.

Giroux, H. (2004). Critical pedagogy and the postmodern/modern divide: Towards a pedagogy of democratization. Teacher Education Quarterly, 31(1 ), pp. 31-47.

Haraway, D.J. (1991). A Cyborg Manifesto: Science, technology, and socialist-feminist in the late twentieth century. In Hopkins, P. D. (Ed.), Sex/Machine: Readings in culture, gender, and technology (pp. 434 - 467). Bloomington: Indiana University Press.

Harris, J. (1997). Art education and cyber-ideologyL Beyond individualism and technological determinism. Art Journal, 3(56), 39-45. 
Healy, J. (1999). Failure to connect: How computers affect our children's minds. New York: Simon \& Schuster/Touchstone.

Hesse-Biber, S. \& Gilbert, M. (1994). Closing the technological gender gap: Feminist pedagogy in the computer-assisted classroom. Teaching Sociology, 22, pp. 19-31.

Hicks, L. (1991). The politics of difference in feminism and multicultural art education. Journal of Multicultural and Cross-Cultural Research in Art Education, 9, 11-26.

hooks, b. (1989). "Toward a revolutionary feminist pedagogy." Talking back: Thinking feminist, thinking black. Boston: South End Press.

Huff, C.W., Fleming, J. H., and Cooper, J. (1992). Gender differences in human-computer interaction. In C. D. Martin and E. Murchie-Beyma (Eds.), In search of gender free paradigms for computer science education. Eugene, OR: International Society for Technology in Education.

Jacobs, J. (n.d.) "Gender Equity for Mathematics and Science, Notes on Invited Faulty Lecture." http://www.woodrow.org/teachers/math/gender/03c-jacobs.html accessed on May 20, 2005.

Jacobs, J. \& Becker, J.R. (1997). Creating a gender-equitable multicultural classroom using feminist pedagogy. National Council of Teachers of Mathematics Yearbook, pp. 107-14.

Jones, A. (Ed.). (2003). The feminism and visual culture reader. New York: Routledge.

Kamhi, M. (2004). Rescuing art from 'visual culture studies'. Arts Education Policy Review. September/October 2004. Accessed at www.aristos.org on May 26, 2005

Kamhi, M. (2003). Where's the art in today's art education? Arts Education Policy Review, 104(4), $9-12$.

Kaplan, A. (1992). Feminist criticism and television. In R. Allen (ed.), Channels of discourse reassembled: Television and contemporary criticism (pp. 247-283). Chapel Hill, NC: University of North Carolina Press.

Kaplan, A. (1983). Is the gaze male? In Women and film: Both sides of the camera (pp. 23-33). New York: Methuen.

Keifer-Boyd, K. (2003). A pedagogy to expose and critique gendered cultural stereotypes embedded in art interpretations. Studies in Art Education, 44 (4), pp. 315-334.

Keifer-Boyd, K. (2004). Cyberfeminist house - Project update. Accessed on October 5, 2005 at http://sva74.sva.psu.edu/ cyberfem/cyberhouse/about.html

Keifer-Boyd, K., Bobbitt, N., Pihlak, M., Dellasega, C., \& Hill, G. (2003). Cyberfeminist house research and development team. Accessed on October 5, 2005 at http://sva74.sva.psu.edu/ cyberfem/cyberhouse/about.html

Keifer-Boyd, K. \& Hill, G. (2001). The beginnings of cyberfeminist house. Accessed on October 5, 2005 at http://sva74.sva.psu.edu/ cyberfem/cyberhouse/about.html

Klawe, M., \& Leveson, N. (1995). Women in computing: Where are we now? Communications of the ACM, 38(1), 29-35.

Kramer, P. E. \& Lehman, S. (1990). Mismeasuring women: A critique of research on computer ability and avoidance. Signs: Journal of Women in Culture and Society, 16 (11), pp. 158172.

Lather, P. (1991). Getting Smart: Feminist research and pedagogy with/in the Postmodern. New York: Routledge.

Lincoln, Y. \& Guba, E. (2000). In N. Denzin \& Y. Lincoln (Eds.), The handbook of qualitative research $\left(2^{\text {nd }}\right.$ ed.) (pp. $\left.163-188\right)$. Thousand Oaks, California: Sage.

Lowenfeld, V. (1947). Creative and mental growth. New York: Macmillan Co. 
Luke, C. and Gore, J. (Eds.), (1992). Feminisms and Critical Pedagogy. New York: Routledge.

Malson, H. (1998). The thin woman: feminism, post-structuralism and the social psychology of anorexia nervosa. New York: Routledge.

Margolis, J. \& Fisher, A. (2003). Unlocking the clubhouse: Women in computing. Cambridge: The MIT Press.

Mirzoeff, N. (1999). An introduction to visual culture. New York, Routledge.

Morse, J. \& Richards, L. (2001). ReadMe first for a user's guide to qualitative methods. Thousand Oaks: Sage.

Mulvey, Laura. (1989). Visual pleasure and narrative cinema. Screen, 16(3), 6-18. Rpt. in Visual and Other Pleasures. Bloomington: Indiana University Press, 1989. 14-27.

Orner, M. (1996). Teaching for the moment: Situated pedagogies. Theory into Practice, 35 (2).

Patterson, L. (1984). Sexual stereotypes taint computer classes. Instructional Innovator, 29 (9): 27.

Relke, D. (1994). Feminist Pedagogy and the Integration of Knowledge: Toward a More Interdisciplinary University. http://www.usask.ca/wgst/journals/conf3.htm. Accessed on May 15, 2005.

Richardson, L. (2000). In N. Denzin \& Y. Lincoln (Eds.), The handbook of qualitative research ( $2^{\text {nd }}$ ed.) (pp. 923 - 948). Thousand Oaks, California: Sage.

Ritchie, J. (1990). Confronting the "essential" problem: Reconnecting feminist theory and pedagogy. JAC, 10(2). http://jac.gsu.edu/jac/10.2/Articles/3.htm. Accessed on May 15, 2005.

Sandell, R. (1991). The liberating relevance of feminist pedagogy. Journal of Issues and Resarch, 32(3), $178-187$.

Sandell, R., \& Spiers, P. (1999). Feminist concerns and gender issues in art education: Translation from theory to practice. Reston, VA: NAEA.

Sanders, J. H., III. (in press).Performing arts-based education research: An epic drama of practice, precursors, problems and possibilities. Studies in Art Education.

Smith, P. (2003). Visual culture studies versus art education. Arts Education Policy Review, 104(4), 3-8.

Spertus, E. (1991). Why Are There So Few Female Computer Scientists? Technical Report 1315. MIT Artificial Intelligence Laboratory.

Stake, R. (2000). In N. Denzin \& Y. Lincoln (Eds.), The handbook of qualitative research (2 ${ }^{\text {nd }}$ ed.) (pp. 435 - 454). Thousand Oaks, California: Sage.

Stinespring, J. (2001). Preventing art education from becoming a handmaiden to the social studies. Arts Education Policy Review, 102(4), 11-18.

Stinespring, J., \& Kennedy, L. (1995). Meeting the need for multiculturalism in the art classroom. The Clearing House, 68(3), 139-145.

Storey. J. (1988). Feminism(s). In An introduction to cultural theory and popular culture (pp. 135-168). Athens, GA: The University of Georgia Press.

Tavin, K (2000). Introduction: The impact of visual culture on art education. The Journal of Multicultural and Cross-Cultural Research in Art Education, 18(1), 20-23.

Tavin, K. (2003). Wrestling with angels, searching for ghosts: Toward a critical pedagogy of visual culture. Studies in Art Education. 44 (3), 197 - 213.

Tavin, K. (2005a). Hauntological shifts: Fear and loathing of popular (visual) culture. Studies in Art Education, 46(2), $101-117$.

Tavin, K. (2005b). Opening Re-Marks: Critical Antecedents of Visual Culture in Art Education. 
Studies in Art Education, 47(1), 5-22.

Tavin, K. \& Anderson, D. (2003). Teaching (popular) visual culture: Deconstructing Disney in the elementary art classroom. Art Education, 56(3), 21-23/32-35.

Taylor, P. (2004). Hyperaesthetics: Making sense of our technomediated world. Studies in Art Education. 45 (4), 328-342.

Taylor, P. (2000). Madonna and hypertext: Liberatory learning in art education. Studies in Art Education, 41(4), 376-389.

Tisdell, E. (1998). Poststructural feminist pedagogies: The possibilities and limitations of feminist emancipatory adult learning theory and practice. Adult Education Quarterly, 48 (3), pp.139-56.

Turkle, S. (1986). "Computational reticence: Why women fear the intimate machine." In C. Kramarae (Ed.), Technology and women's voices, 41-61. New York: Pergamon Press.

Turkle, S. (1995). Life on the screen: Identity in the age of the internet. New York: Simon and Schuster.

Ullman, E. (1995). Out of time: Reflections on the programming life. In J. Brook \& I. Boal (Eds.), Resisting the virtual life: The culture and politics of information, pp. 131-144. San Francisco, City Lights.

Weedon, C. (1997). Feminist practice and poststructuralist theory ( $2^{\text {nd }}$ edition). Cornwall, UK: Blackwell Publishing.

Weiler, K. (1988). Women teaching for change: Gender, class and power. South Hadley, MA: Bergin \& Garvey.

Wittig, M. (1981). One is not born a woman. The straight mind and other essays. Boston: Beacon Press.

Wolbier, J. A. (2003). The history and current status of visual arts education in American schools. Unpublished research paper. Accessed on June 21, 2006, from http://www.his.com/ jwolbier/Planning.html

www.accad-osu.edu 